\title{
Colchicine poisoning related rhabdomyolysis in a child
}

\section{To the Editor,}

Colchicine is a natural alkaloid obtained from the plant of Colchicum Autumnale which has anti-inflammatory action. It is a drug used in Behçet's disease, goute arthritis, scleroderma and especially in prevention of acute attacks of Familial Mediteranean Fever (FMF) and development of amiloidosis (1). Frequent use of colchicine in relation with the high prevalence of FMF has caused to an increase in cases of intoxication. Especially high doses lead to mortality. In a study performed by Özdemir et al. (2) in 23 pediatric patients who were diagnosed as colchicine intoxication between 1985 and 2011, no mortality was observed in 16 patients who received less than $0.5 \mathrm{mg} / \mathrm{kg}$ colchicine, while one of three patients who received a dose of $0.5-0.8 \mathrm{mg} / \mathrm{kg}$ and one of four patients who received more than $0.8 \mathrm{mg} / \mathrm{kg}$ were lost. Rhabdomyolysis related to colchicine has been reported rarely and it is important in terms of mortality risk (3). We present a pediatric patient who developed rhabdomyolysis and bone marrow supression following ingestion of high dose colchicine accidentally.

A 3-year-old female patient presented to a hospital one hour after ingesting 10 tablets each containing $0.5 \mathrm{mg}$ colchicine $(0.4$ $\mathrm{mg} / \mathrm{kg}$ ). She was discharged after gastric lavage and administration of active carchoal. She presented to our hospital becasue of vomiting and malaise which started 48 hours later. On physical examination the body temperature was found to be $37,1^{\circ} \mathrm{C}$ (axillary), the pulse was found to be $95 / \mathrm{min}$, the respiratory rate was found to be $28 / \mathrm{min}$, the blood pressure was found to be $90 / 60 \mathrm{mmHg}$. Other physical examination findings were found to be normal. In the laboratory tests, aspartate transaminase (AST) was found to be $826 \mathrm{U} / \mathrm{L}$ and alanine aminotransferase (ALT) was found to be $146 \mathrm{U} / \mathrm{L}$ (5-50). Thrombocytopenia was present $\left(50000 / \mathrm{mm}^{3}\right)$. The patient was internalized for follow-up.

On the following day, diffuse muscle pain was found on examination and the laboratory tests were repeated: AST: 395 U/L, ALT: $132 \mathrm{U} / \mathrm{L}$, lactate dehydrogenase (LDH): $2094 \mathrm{U} / \mathrm{L}$ (150-
500), creatinine kinase (CK): $6530 \mathrm{U} / \mathrm{L}$ (35-235), myoglobin:117 $\mathrm{ng} / \mathrm{mL}$ (21-58), sodium $131 \mathrm{mEq} / \mathrm{L}$, potassium $2.9 \mathrm{mEq} / \mathrm{L}$, chloride $101 \mathrm{mEq} / \mathrm{L}$ and phosphate $1.7 \mathrm{mg} / \mathrm{dL}$. On the second day of hospitalization, leukopenia $\left(3600 / \mathrm{mm}^{3}\right)$ was added to thrombocytopenia. Blood urea nitrogen, creatinine, blood gases, calicum, fibrinogen, prothrombin time and activated partial thromboplastin time were found to be normal. Medical history did not reveal any infection, trauma, intramuscular injection or use of drugs other than colchicine which could cause rhabdomyolysis. The picture was considered as rhabdomyolysis related with colchicine. Fluid (2500 cc/m²/gün) and alkalinization treatment was administered. No other pathology was found in the follow-up and the patient was discharged four days later because her physical examination and laboratory findings improved.

Colchicine intoxication is a rare, but life-threatenting toxicological emergency. High doses are fatal. Toxicity may be observed even with therapeutic doses. Colchicine intoxication is divided into three stages according to clinical findings:

Stage 1: In this stage, intestinal mucosal cells with high division rate are affected. Accordingly, the most common initial findings include nausea, vomiting, abdominal pain and diarrhea.

Stage 2: This stage starts 24 hours after colchicine ingestion. Findings related with multiple organ failure start to be observed in relation with involvement of some systems. Bone marrow supression, hepatic damage, renal failure, respiratory distress syndrome, arythmias, disseminated intravascular coagulation, metabolic acidosis, hyponatremia and hypokalemia are observed in this stage.

Stage 3: The third stage is the recovery stage. In this stage, transient alopecia and "rebound" leukocytosis are observed typically (4).

Death may occur in the early period (the first 48 hours) because of hypovolemic shock, central nervous system damage or cardiopulmonary failure (5). It occurs frequently in the late period (after 7-10 days) because of cardiogenic collapse or bone marrow supression (6). 
Rhabdomyolysis is a picture characterized with diffuse muscle damage which develops in relation with different etiologies. Myoglobin which may lead to acute tubular necrosis is a significant product of muscle destruction and is released into the plasma $(7,8)$. Association of muscle pain, muscle weakness and dark colored urine observed in adults is rare in children. Muscle pain and diffuse muscle weakness are the most common complaints in children. The diagnosis is made with increased CK levels accompanying muscle pains and presence of myoglobinuria. Life threatening complications including renal failure and disseminated intravascular coagulation are observed more frequently in adults $(9,10)$. Our patient had increased muscle tenderness and malaise.

Colchicine intoxication is a rare cause of rhabdomyolysis in children. In the study performed by Melli et al. (11), $7 \%$ of the cases of rhabdomyolysis related to drug ingestion were found to be secondary to colchicine intoxication. In most of these patients, a second drug ingestion was present (antipsychotic, statin and serotonin reuptake inhibitors). In the literature, colchicine-related rhabdomyolysis has been reported in four pediatric patients $(12,13,14)$. The doses used by the patients ranged beween 07 and $1.3 \mathrm{mg} / \mathrm{kg}$. The most common complaint at presentation included vomiting and diarrhea. The most common clinical findings included sepsis-septic shock, disseminated intravascular coagulation and alopesia. One child was lost. In our patient, the diagnosis of rhabdomyolysis was made because $\mathrm{CK}$ and myoglobulin values which were measured because of muscle pain which started 48 hours after ingestion of $0.4 \mathrm{mg} / \mathrm{kg}$ colchicine were found to be high.

All patients with a suspicion of colchicine intoxication should be monitored closely, since the outcome can not be predicted. The clinical and laboratory findings should be followed up closely and rhabdomyolysis should be considered in patients with severe muscle pain.

\section{Fatih Demircioğlu1, Elif Kazanc12, Hakan Edoğan3, Mervan Bekdaş', Sevil Göksügür1}

${ }^{1}$ Abant lzzet Baysal University Medical Faculty, Department of Pediatrics, Bolu, Turkey

2Abant Izzet Baysal University Medical Faculty, Dörtçelik Children's Hospital, Division of Pediatric Hematology, Bolu, Turkey

3Abant lzzet Baysal University Medical Faculty, Dörtcelik Children's Hospital, Division of Pediatric Nephrology, Bolu, Turkey

\section{References}

1. Ben-Chetrit E, Bergmann S, Sood R. Mechanism of the anti-inflammatory effect of colchicine in rheumatic diseases: a possible new outlook through microarray analysis. Rheumatology (Oxford) 2006; 45(3): 274-282.

2. Ozdemir R, Bayrakci B, Teksam O. Fatal poisoning in children: acute colchicine intoxication and new treatment approaches. Clin Toxicol (Phila) 2011; 49(8): 739-743.

3. Bismuth C, Gaultier M, Conso F. Aplastic médullaire aprés intoxication aigue á la colchicine. Nouv Presse Med 1977; 6: 1625-1629.

4. Milne ST, Meek PD. Fatal colchicine overdose: report of a case and review of the literature. Am J Emerg Med 1998; 16(6): 603-608.

5. Stapczynski JS, Rothstein RJ, Gaye WA, Niemann JT. Colchicine overdose: report of two cases and review of the literature. Ann Emerg Med 1981; 10(7): 364-369.

6. Ben-Chetrit E, Levy M. Colchicine: 1998 update. Semin Arthritis Rheum 1998; 28(1): 48-59.

7. Harris R, Marx G, Gillett M, Kark A, Arunanthy S. Colchicine-induced bone marrow suppression: treatment with granulocyte colonystimulating factor. J Emerg Med 2000; 18(4): 435-440.

8. Criddle L. Rhabdomyolysis. Pathophysiology, recognition, and management. Critical Care Nurse 2003; 23(6): 14-32.

9. Mannix R, Tan ML, Wright R, Baskin M. Acute pediatric rhabdomyolysis: causes and rates of renal failure. Pediatrics 2006; 118(5): 2119-2125.

10. Watemberg N, Leshner RL, Armstrong BA, Lerman-Sagie T. Acute pediatric rhabdomyolysis. J Child Neurol 2000; 15(4): 222-227.

11. Vanholder R, Sever MS, Erek E, Lameire N. Rhabdomyolysis. J Am Soc Nephrol 2000; 11(8): 1553-1561.

12. Melli G, Chaudhry V, Cornblath DR. Rhabdomyolysis: an evaluation of 475 hospitalized patients. Medicine (Baltimore) 2005; 84(6): 377-385.

13. Biçer S, Soysal DD, Ctak A, Uçsel R, Karaböcüoğlu M, Uzel N. Acute colchicine intoxication in a child: a case report. Pediatr Emerg Care 2007; 23(5): 314-317.

14. Güven AG, Bahat E, Akman S, Artan R, Erol M. Late diagnosis of severe colchicine intoxication. Pediatrics 2002; 109(5): 971-973. 